\title{
RELATIONSHIP OF ORGANIC MATERIAL WITH ABUNDANCE OF TOXIC BENTHIC DINOFLAGELLATA ON SEDIMENT IN WATERS OF TELUK BAKAU VILLAGE BINTAN REGENCY, RIAU ISLAND PROVINCE
}

\author{
Syafrinaldi Afrizani $^{1^{*}}$ Irvina Nurrachmi $^{2}$ Irwan Effendi $^{3}$ \\ ${ }^{1}$ Student of The Faculty of Fisheries And Marine Science University of Riau, Pekanbaru \\ ${ }^{2}$ Lecturer at the Faculty of Fisheries And Marine Science University Riau, Pekanbaru \\ *syafrinaldiafrizani4@gmail.com
}

\begin{abstract}
Dinoflagellata was included in one of microalgae groups which are on waters of the sea and the river, it can be found on detritus floats, sediments, and also swim freely. This research done on May - June 2018 at waters of the mangrove bay village, Bintan Regency, Riau Island Province. The aims of this research was to know relationship between organic material concentration toward abundance of toxic benthic dinoflagellata on sediment. In addition, to analyzed organic material concentratin and amount of abundance of toxic benthic dinoflagellata on sediment in waters of Teluk Bakau. The method used was survey method which is the location of sampling is done by pursosive sampling. Measurement of water quality sampling done at any point, the surface water temperature range 31-33oC, 28-31\%o salinity, $\mathrm{pH} 8-9$ and the current speed from 0.045 to $0.051 \mathrm{~m} /$ det.Perairan predominantly sandy gravel sediments, making an average of organic materials ditemukn at each station is $0.027 \%, 0.043 \%, 0.033 \%, 0.024 \%$. The result of this research found 3 genus of toxic dinoflagellata, which are Prorocentrum, Gambierdiscus, and Ostreopsis. Poisonous dinoflagelatta can produced a several types of toxic that found the sea. The highest of abundance found at station 2 on $75,615 \mathrm{sel} / \mathrm{m}^{2}$ and the lowest found at station 1 on 35,176 $\mathrm{sel} / \mathrm{m}^{2}$. the results of simple linear regression analysis the relationship between the concentration of organic material with the abundance of dinoflagellates has a positive relationship with the regression equation $y=32,913+556,13 x$
\end{abstract}

Keyword : Dinoflagellata, Sediments, Organic Material, Malang Rapat

\section{PENDAHULUAN}

Dinoflagellata termasuk dalam salah satu kelompok mikroalga yang berada pada perairan laut maupun sungai, Dinoflagellata memiliki peran penting dalam perairan yaitu sebagai produser primer. Habitat dinoflagellata umunya berada di pasir, detritus yang mengapung, menempel di permukaan makroalga dan terumbu karang, serta sisanya kadang berenang bebas tetapi masih dekat dengan permukaan tempat berasosiasi dengan lingkungan disekitarnya. Menurut Faust (2000) dijelaskan bahwa keberadaan dinoflagellata ini ditemukan di berbagai lingkungan perairan, sehingga dinoflagllata mempunyai sifat ekologi yang kompleks. Dinoflagellata terbagi menjadi dua kelompok yaitu dinoflagellata yang tidak beracun dan dinoflagellata beracun. Kelompok dinoflagellata yang tidak beracun memiliki peran penting dalam perairan yaitu sebagai produsen primer, selain itu dinoflagellata juga memiliki fungsi sebagai pakan alami. Sedangkan dinoflagellata beracun seperti Gambierdiscus, Prorocentrum dan Ostreopsis dapat menghasilkan beberapa jenis toksin yang dijumpai di laut antara lain Tetrodotoxin, Ciguatoxic, Paralytic 
Shellfish Poison (PSP), dan beberapa toksin lainnya. Diantara racun tersebut yang paling membahayakan pada ikan adalah Ciguatera Fish Poisoning (Ciguatoxic) (Seygita et al., 2015). Desa Teluk Bakau merupakan salah satu desa pesisir Bintan yang memiliki pantai dengan substrat berpasir. Pada daerah ini terdapat pelabuhan, tempat penampungan ikan, pemukiman warga, tempat wisata dan banyak aktivitas manusia lainnya, dikhawatirkan banyaknya aktivitas manusia ini dapat merubah kondisi fisik dan kimia perairan.

Aktivitas manusia tersebut mempengaruhi pola dan karakteristik sedimen di perairan Desa Teluk Bakau, sehingga pengaruh tersebut juga terjadi pada kandungan bahan organik pada sedimen wilayah perairan tersebut.

Bahan organik pada sedimen juga berpengaruh terhadap kehidupan di lingkungannya. Senyawa organik sebagian besar terdapat dalam jaringan organisme yang berperan sangat penting dalam rantai makanan yaitu sebagai sumber makanan dan energi bagi organisme heterotroph, dalam siklus nutrien dalam ekosistem. Bahan organik yang disuplai ke sedimen laut berasal dari dua sumber utama, yaitu berasal dari sistem sedimen itu sendiri (autochtonous) dan berasal dari luar sistem sedimen (allochtomnous) yang disuplai dari ekosistem lain. Input bahan organik ke sedimen laut dangkal berasal dari autochtonous, berupa fraksi hidup dan fraksi bukan hidup (Ira, 2011).

Tingginya bahan organik di dalam perairan akan memberikan pengaruh yang kuat terhadap ketersediaan oksigen terlarut, apabila keadaan ini berlangsung lama akan menyebabkan perairan menjadi anaerob (Marwan, 2012).

Tujuan penelitian ini untuk mengetahui hubungan antara konsentrasi bahan organik terhadap kelimpahan dinoflagellata bentik beracun pada sedimen. Selain itu juga menganalisis konsentrasi bahan organik dan jumlah kelimpahan dinoflagellata bentik beracun pada sedimen. di perairan Teluk Bakau

\section{METODE PENELITIAN}

Waktu dan Tempat Penelitian Penelitian ini dilaksanakan dalam dua tahap. Tahap pertama pengambilan sampel di perairan Desa Teluk Bakau Kabupaten Bintan pada bulan Mei 2018. Tahap kedua analisis sampel dan pengolahan data di Laboratorium Kimia Laut Universitas Riau pada bulan Juni 2018. Lokasi pengambilan sampel di bagi menjadi 4 stasiun, setiap stasiun dibagi menjadi 3 titik sampling. (Gambar 1). 


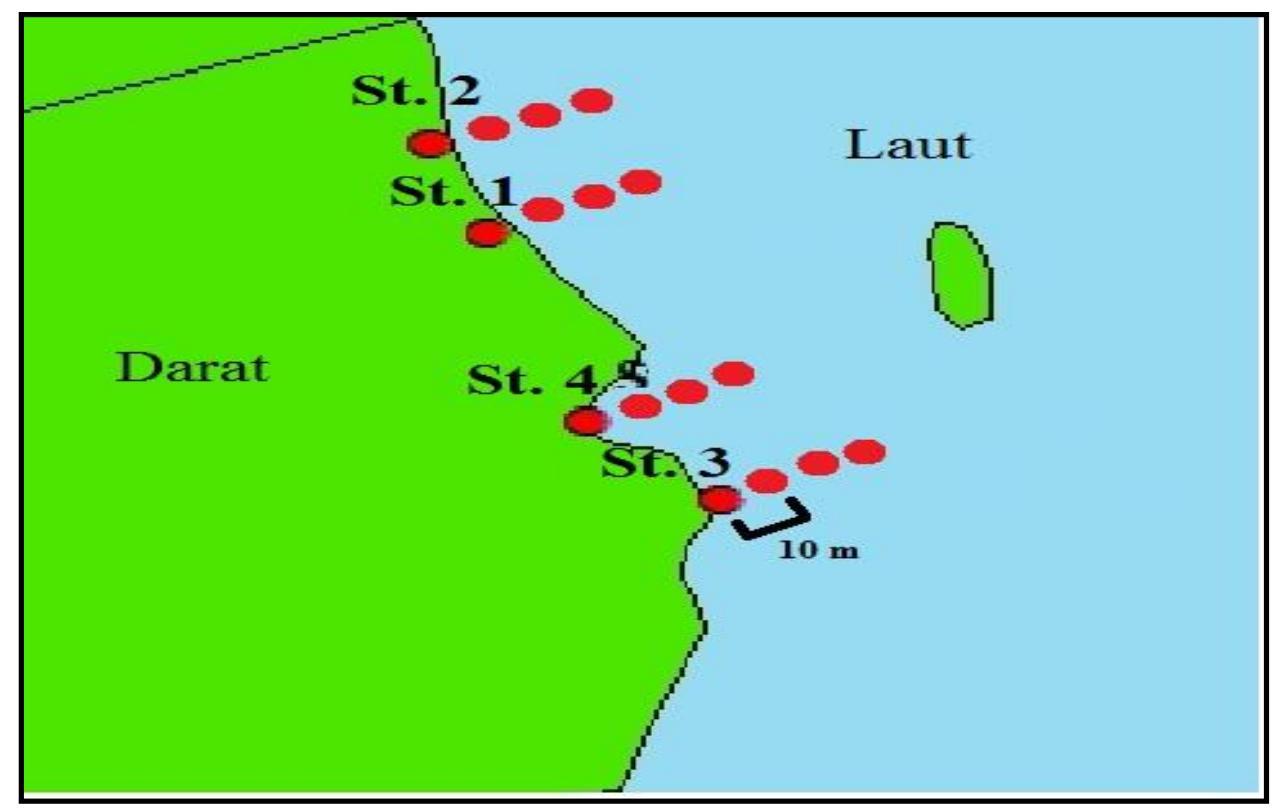

Gambar 1. Peta Titik Sampling Penelitian Desa Teluk Bakau

\section{Pengambilan sampel}

Pengambilan sampel dinoflagellata bentik yang menempel pada Sedimen

dilakukan dengan mengikuti metode YESOU (2013). Dalam penelitian ini yang menjadi sampel penelitian adalah sedimen.

1. Sampel dinoflagellata diambil pada setiap plot (1m x 1m) yang dimana pada setiap plot terdiri dari sub plot $(33,3 \mathrm{~cm}$ x $33,3 \mathrm{~cm})$. Sampel diambil secara acak sebanyak 3 kali dengan cara mengunakan spatula dan kemudian dimasukan ke dalam kantong plastik yang telah berisi air laut.

2. Air sampel di dalam kantong plastik dikocok terlebih dahulu agar bias melepaskan dinoflagellata dari sedimen, kemudian air sampel disaring sebanyak $1000 \mathrm{ml}$ menggunakan saringan berukuran 350 mikron untuk memisahkan sedimen dengan sampel dinoflagellata, kemudian ditimbang berat sedimen.

3. Air sampel disaring kembali menggunakan vacum pump dengan plastik screen berukuran 20 mikron, selanjutnya plastik screen yang telah disaring dimasukan ke dalam botol sampel yang telah diisi air laut steril sekitar $15 \mathrm{ml}$ kemudian ditambahkan lugol 4\% sebanyak 2 tetes lalu ditutup rapat. Botol sampel diberi label sesuai stasiun masing-masing.

4. Kemudian sampel dimasukkan ke dalam box dan dianalisis di laboratorium.

\section{Pengukuran kualitas air}

Pengukuran kualitas air selama penelitian diperlukan sebagai data pendukung untuk mengetahui kondisi perairan. Pengukuran dilakukan di setiap titik sampling dengan parameter-parameter fisika dan kimia yaitu : suhu, $\mathrm{pH}$, salinitas, dan kecepatan arus. Pengambilan sampel sedimen untuk bahan organik dan fraksi sedimen dilakukan pada saat air surut, yaitu sedimen yang diambil pada bagian permukaan sedimen.

\section{Perhitungan Kelimpahan Dinoflagellata.}

Hasil kelimpahan Dinoflagellata dihitung dengan menggunakan rumus Yesou (2013): 


$$
\text { Kelimpahan }\left(\mathrm{sel} / \mathrm{m}^{2}\right)=\frac{\text { Avg cells }}{\text { Vol counted }} \times \frac{\text { Vol Tube }}{\text { Vol Filtered }} x \frac{\text { Vol Sample }}{\text { Area of Sediment }} \times 100
$$

Keterangan :

Avg cells = Rata rata cell

Vol counted = Volume satu tetes $(1 \mathrm{ml})$

Vol tubed = Volume botol sempel $(\mathrm{ml})$

Vol filltered $=$ Volume air yang tersaring $(\mathrm{ml})$

Vol sample = Volume air yang diambil $(\mathrm{ml})$

Area of sediment $=$ Luas sedimen yang diambil $\left(\mathrm{m}^{2}\right)$

Data yang diperoleh dari pengambilan sampel akan disajikan dalam bentuk tabel dan grafik untuk dibahas secara deskriptif yang dihubungkan dengan kondisi perairan yang ada. Untuk kelimpahan dinoflagellata dan perhitungan bahan organik dihitung menggunakan Software Microsoft Excell 2007. Selanjutnya dilakukan perhitungan statistik yakni uji regresi linier untuk melihat keeratan bahan organik sedimen terhadap kelimpahan dinoflagellata dengan persamaan:

dimana:

$$
y=a+b x
$$

y : Kelimpahan dinoflagellata $\left(\mathrm{sel} / \mathrm{m}^{2}\right)$

a dan $\mathrm{b}:$ Konstanta

$\mathrm{x} \quad$ : Bahan Organik

Untuk mengetahui keeratan hubungan bahan organik terhadap kelimpahan dinoflagellata digunakan koefisien korelasi (r) dimana nilai $r$ berada antara 0-1. menurut Sugiyono (2008) keeratan nilainya yaitu :
- $0,00-0,199=$ Hubungan sangat lemah

- $0,20-0,399=$ Hubungan lemah

- $0,40-0,599=$ Hubungan sedang

- $0,60-0,799=$ Hubungan kuat

- $0,80-1,000=$ Hubungan sangat kuat

\section{HASIL DAN PEMBAHASAN}

\section{Keadaan Umum Lokasi Penelitian.}

Secara administratif Desa Teluk Bakau memiliki luas wilayah $\pm 112,12$ $\mathrm{km} 2$ dengan batas-batas sebagai berikut : Sebelah utara berbatasan dengan Desa Malang Rapat, Kecamatan Gunung Kijang; Sebelah selatan berbatasan dengan Kelurahan Kawal, Kecamatan Gunung Kijang; Sebelah barat berbatasan dengan Desa Toapaya Utara; Sebelah timur berbatasan dengan Laut Cina Selatan (Kantor Desa Teluk Bakau, 2018). Suhu pada waktu siang dan malam tidak jauh berbeda berkisar pada $37^{\circ} \mathrm{C}$.

\section{Parameter Kualitas Perairan.}

Pengukuran ini dilakukan pada siang hari di waktu surut. Hasil pengukuran parameter kualitas perairan dapat dilihat pada Tabel 1.

Tabel 1. Pengukuran Parameter Kualitas Perairan di Desa Teluk Baka

\begin{tabular}{ccccc}
\hline \multirow{2}{*}{ Stasiun } & \multicolumn{4}{c}{ Parameter Kualitas Perairan (Satuan) } \\
\cline { 2 - 5 } & Suhu $\left({ }^{\circ} \mathrm{C}\right)$ & Salinitas $(\%)$ & $\mathrm{pH}$ & $\begin{array}{c}\text { Kecepatan Arus } \\
(\mathrm{m} / \mathrm{det})\end{array}$ \\
\hline 1 & 33 & 30 & 8 & 0,051 \\
\hline 2 & 33 & 31 & 8 & 0,049 \\
\hline 3 & 31 & 28 & 9 & 0,045 \\
\hline 4 & 31 & 29 & 9 & 0,049 \\
\hline
\end{tabular}


Berdasarkan Tabel 1. diketahui kisaran suhu permukaan perairan pada lokasi penelitian berkisar $31-33^{\circ} \mathrm{C}$, salinitas berkisar 28-31\%o, pH 8-9 dan kecepatan arus berkisar 0,045-0,051 m/det.
Fraksi Sedimen dan Bahan Organik.

Persentase fraksi sedimen dan jenisnya di perairan Desa Teluk Bakau dapat dilihat pada Tabel 2.

Tabel 2. Fraksi Sedimen Dasar Perairan di Desa Teluk Baka

\begin{tabular}{|c|c|c|c|c|c|}
\hline \multirow{2}{*}{ Stasiun } & \multirow{2}{*}{$\begin{array}{c}\text { Titik } \\
\text { Sampling }\end{array}$} & \multicolumn{3}{|c|}{ Fraksi sedimen $(\%)$} & \multirow{2}{*}{ Jenis Sedimen } \\
\hline & & Kerikil & Pasir & Lumpur & \\
\hline \multirow{3}{*}{1} & 1 & 58,42 & 30,92 & 10,66 & Kerikil Berpasir \\
\hline & 2 & 56,22 & 32,46 & 11,32 & Kerikil Berpasir \\
\hline & 3 & 45,77 & 43,52 & 10,71 & Kerikil Berpasir \\
\hline \multirow{3}{*}{2} & 1 & 49,46 & 11,75 & 38,79 & Kerikil berlumpur \\
\hline & 2 & 52,02 & 16,97 & 31,01 & Kerikil berlumpur \\
\hline & 3 & 31,11 & 39,61 & 29,28 & Pasir+Kerikil+lumpur \\
\hline \multirow{3}{*}{3} & 1 & 53,58 & 29,30 & 17,13 & Kerikil berpasir \\
\hline & 2 & 70,24 & 16,28 & 13,47 & Kerikil Berpasir \\
\hline & 3 & 48,57 & 35,38 & 16,06 & Kerikil Berpasir \\
\hline \multirow{3}{*}{4} & 1 & 24,26 & 65,07 & 10,67 & Pasir Berkerikil \\
\hline & 2 & 72,23 & 16,27 & 11,50 & Kerikil Berpasir \\
\hline & 3 & 50,15 & 39,19 & 10,66 & Kerikil Berpasir \\
\hline
\end{tabular}

Berdasarkan hasil analisis fraksi sedimen pada perairan Desa Teluk Bakau merupakan kerikil berpasir (Sandy Gravel) hingga pasir berkerikil (Gravelly Sand). Ukuran butiran sedimen di perairan Desa Teluk Bakau yang kasar ini juga disebabkan dengan kondisi arus perairan yang cenderung kuat. Hal ini sesuai dengan pendapat Nugroho dan Basit (2014), adanya sedimen halus diendapkan pada arus dan gelombang yang benar-benar tenang, sedangkan sedimen berukuran kasar menunjukkan bahwa arus dan gelombang pada daerah itu relatif kuat, fraksi kasar umumnya diendapkan pada daerah terbuka yang berhubungan dengan laut lepas.

Bahan organik merupakan salah satu parameter kualitas perairan yang dapat dijadikan sebagai penentu kesuburan perairan karena bahan organik digunakan sebagai sumber nutrien bagi mikroalga atau dinoflagellata di sedimen. Hasil pengukuran konsentrasi bahan organik dapat dilihat pada Tabel 3. 
Tabel 3. Analisis Bahan Organik (\%)

\begin{tabular}{cccc}
\hline Stasiun & Titik Sampling & $\begin{array}{c}\text { Total Bahan Organik } \\
(\boldsymbol{\%})\end{array}$ & $\begin{array}{c}\text { Rata-rata Bahan } \\
\text { Organik (\%) }\end{array}$ \\
\hline \multirow{2}{*}{1} & 1 & 0,030 & \\
& 2 & 0,027 & $0,027 \pm 0,002$ \\
\hline \multirow{2}{*}{2} & 1 & 0,026 & \\
& 2 & 0,045 & $0,043 \pm 0,006$ \\
\hline \multirow{3}{*}{3} & 3 & 0,035 & \\
& 1 & 0,049 & $0,033 \pm 0,024$ \\
\hline \multirow{3}{*}{4} & 2 & 0,016 & \\
& 3 & 0,017 & $0,024 \pm 0,002$ \\
\hline
\end{tabular}

Bahan organik tertinggi terdapat pada stasiun 2 dengan konsentrasi rata-rata $0,043 \%$ sementara yang terendah pada stasiun 4 dengan konsentrasi 0,024\%. Untuk lebih jelasnya persentase bahan organik di perairan Teluk Bakau dapat dilihat pada Gambar 2.

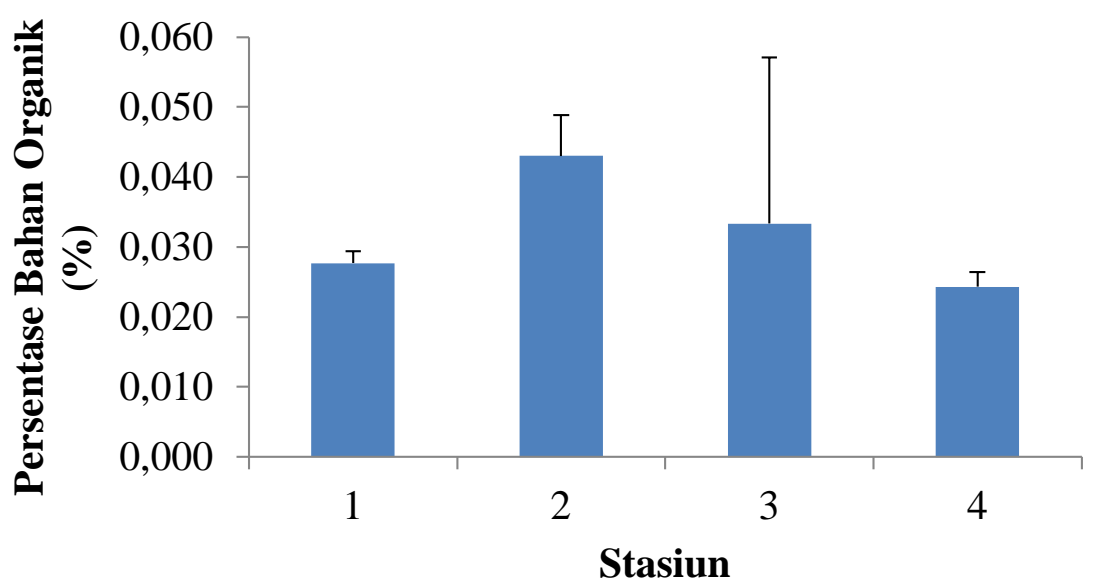

Gambar 2. Persentase Bahan Organik di Perairan Teluk Bakau

Persentase bahan organik dalam suatu sedimen sangat berhubungan dengan tekstur atau jenis fraksi sedimen pada suatu perairan. Semakin tinggi kandungan fraksi lumpur/lempung dan liat dalam sedimen yang diperoleh, maka kandungan bahan organik semakin tinggi. Sebaliknya, semakin rendah kandungan fraksi lumpur/lempung dan liat dalam sedimen, maka kandungan bahan organik semakin rendah. Hal ini diperkuat oleh Supriyadi (2008) dan Bengen (2002) bahwa bahan organik cenderung meningkat dengan meningkatnya kandungan lempung dan liat. Terlihat pada persentase stasiun 2 yang tinggi menunjukkan bahwa banyak mengandung lumpur atau liat.

\section{Distribusi dinofalgellata}

Berdasarkan identifikasi yang telah dilakukan ditemukan 3 genus dinoflagellata bentik pada sedimen di kawasan perairan Desa Teluk Bakau yaitu genus Gambierdiscus, Ostreopsis dan 
Prorocentrum. Masing-masing genus mempunyai distribusi yang berbeda pada

tiap stasiun, untuk lebih jelasnya dapat dilihat pada Tabel 4.

Tabel 4. Distribusi Dinoflagellata Bentik Beracun

\begin{tabular}{cccc}
\hline \multirow{2}{*}{ Stasiun } & \multicolumn{3}{c}{ Genus Dinoflagellata ditemukan } \\
\cline { 2 - 4 } & Gambierdiscus & Ostreopsis & Prorocentrum \\
\hline 1 & + & + & + \\
\hline 2 & + & + & + \\
\hline 3 & + & + & + \\
\hline 4 & + & + & + \\
\hline
\end{tabular}

Keterangan: (+) Ditemukan

(-) Tidak ditemukan

Hasil dari penelitian yang dilakukan ditemukan 3 genus pada lokasi penelitian yang terdistribusi pada masingmasing stasiun, yaitu genus Gambierdiscus, Ostreopsis dan Prorocentrum (Tabel 4). Menurut Bomber et al. (1985), disebutkan bahwa kelompok Prorocentrum memiliki kemampuan adaptasi yang lebih tinggi dibandingkan kelompok mikroorganisme bentik lainnya. Hal ini menyebabkan genus Prorocentrum dapat ditemukan pada setiap stasiun penelitian. Hal yang sama juga diungkapkan oleh GEOHAB (2001) bahwa genus Prorocentrum juga mempunyai toleransi yang luas terhadap lingkungan yang berbeda dan dapat tersebar luas, serta dinoflagellata pada genus ini bersifat kosmopolit.

Genus Gambierdiscus juga ditemukan hampir pada setiap stasiun penelitian. Hal ini Menurut Delgado et al., (2006) dinoflagellata dari genus Gambierdiscus sp umumnya melimpah pada saat kondisi angin yang lemah, laut yang tenang, dan transparansi air yang meningkat. Dengan ditemukannya genus ini pada masing-masing stasiun maka kemungkinan untuk terserang oleh toksik yang dibawa genus ini juga akan semakin besar. Genus Gambierdiscus merupakan kontributor utama dari penyakit Ciguatera Fish Poisoning (CFP) (Nitajohan, 2008). Apalagi biasanya Ciguatera dapat muncul pada daerah yang sebelumnya belum pernah terjangkit penyakit ini, didukung dengan adanya kerusakan terhadap lingkungan ekosistem (Anderson dan Lobel, 1987). Dimana lokasi penelitian terjadi pengerusakan ekositem.

\section{Nilai kelimpahan dinoflagellata}

Kelimpahan yang ditemukan pada perairan Desa Teluk Bakau saat penelitian berbeda-beda untuk masing-masing stasiun yang dapat dilihat pada Tabel 5. Nilai kelimpahan dinoflagellata dapat menjadi penentu kesuburan suatu wilayah perairan karena berhubungan dengan fenomena HABs (Harmful Algae Blooms). Apabila di suatu perairan terjadi fenomena HABs maka dapat dipastikan bahwa perairan tersebut berbahaya bagi biota di dalamnya dan biota tersebut tidak bisa dikonsumsi

Tabel 5. Rata - rata Kelimpahan Dinoflagellata Bentik Beracun $\left(\mathrm{sel} / \mathrm{m}^{2}\right)$

\begin{tabular}{cccccc}
\hline \multirow{2}{*}{ No } & \multirow{2}{*}{ Genus } & \multicolumn{4}{c}{ Kelimpahan Dinoflagellata } \\
\cline { 3 - 5 } & & 1 & 2 & 3 & 4 \\
\hline 1 & Prorocentrum & 18,496 & 46,333 & 28,541 & 25,576 \\
2 & Gambierdiscus & 7,784 & 18,533 & 13,344 & 15,568 \\
3 & Ostreopsis & 5,931 & 10,749 & 5,9307 & 6,672 \\
\hline & Total $\left(\mathrm{sel} / \mathrm{m}^{2}\right)$ & 35,176 & 75,615 & 47,816 & 47,816 \\
\hline
\end{tabular}


Berdasarkan Tabel 5 disebutkan bahwa kelimpahan dinoflagelata pada sedimen tertinggi pada stasiun 2 dengan nilai kelimpahan $75,615 \mathrm{sel} / \mathrm{m}^{2}$ dan yang terendah di stasiun 1 dengan nilai kelimpahan 35,176 sel $/ \mathrm{m}^{2}$. Untuk lebih jelasnya kelimpahan dinoflagelata pada tiap stasiun dapat dilihat pada Gambar 3

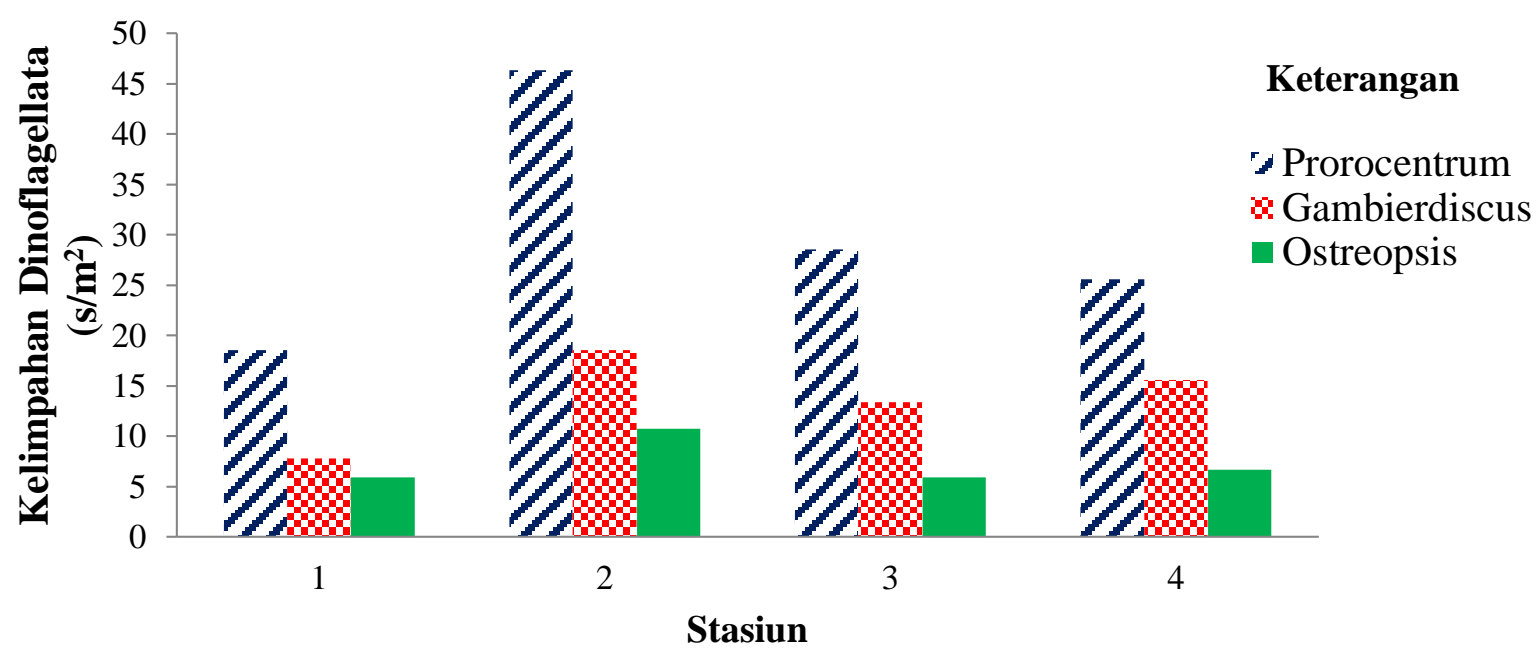

.Gambar 3. Kelimpahan Dinoflagellata pada Setiap Stasiun

Kelimpahan pada genus yang tertinggi adalah pada stasiun 2 genus Prorocentrum dengan 46,333 sel $/ \mathrm{m}^{2}$. Sementara staiun 4 genus dengan kelimpahan terendah adalah Ostreopsis dengan nilai $6,672 \mathrm{sel} / \mathrm{m}^{2}$.

Dinoflagellata dapat menunjukkan kondisi ekologis sebagai penentu kesuburan suatu perairan melalui perhitungan nilai kelimpahannya (Eboni, 2015). Umumnya kelimpahan dinoflagellata bergantung pada kandungan nutrien dalam suatu perairan yaitu apabila suatu perairan kaya akan nutrien, maka kelimpahan dinoflagellata juga akan semakin tinggi (Lalli dan Parsons 2006). Pernyataan tersebut juga didukung oleh pendapat Roito (2014) yang menyatakan bahwa tingginya kelimpahan fitoplankton dipengaruhi oleh aktivitas masyarakat sehari-hari yang terdapat banyak buangan limbah rumah tangga sehingga banyak masukan bahan anorganik.
Kelimpahan dinoflagellata yang tinggi ditemukan pada stasiun 2 diduga karena pada stasiun ini memiliki kecepatan arus yang lemah yaitu $0,049 \mathrm{~m} / \mathrm{det}$. Sedangkan kelimpahan dinoflagellata terendah ditemukan pada stasiun 1 dan merupakan stasiun dengan kecepatan arus yang cukup kuat dengan nilai yaitu 0,051 $\mathrm{m} /$ det, sehingga diduga dapat memicu tumbuhnya dinoflagellata secara berkala. Arus perairan yang lemah memperkecil pergerakan mikroorganisme dinoflagelata bentik yang dipengaruhi oleh arus (Dwivayana et al., (2015).

\section{Analisis hubungan konsentrasi bahan organic terhadap kelimpahan dinoflagelata}

Analisis dilakukan dengan menggunakan persamaan regresi linear sederhana. Hasil analisis regresi linear sederhana konsentrasi bahan organik terhadap kelimpahan dinoflagellata dapat dilihat pada Gambar 4. 


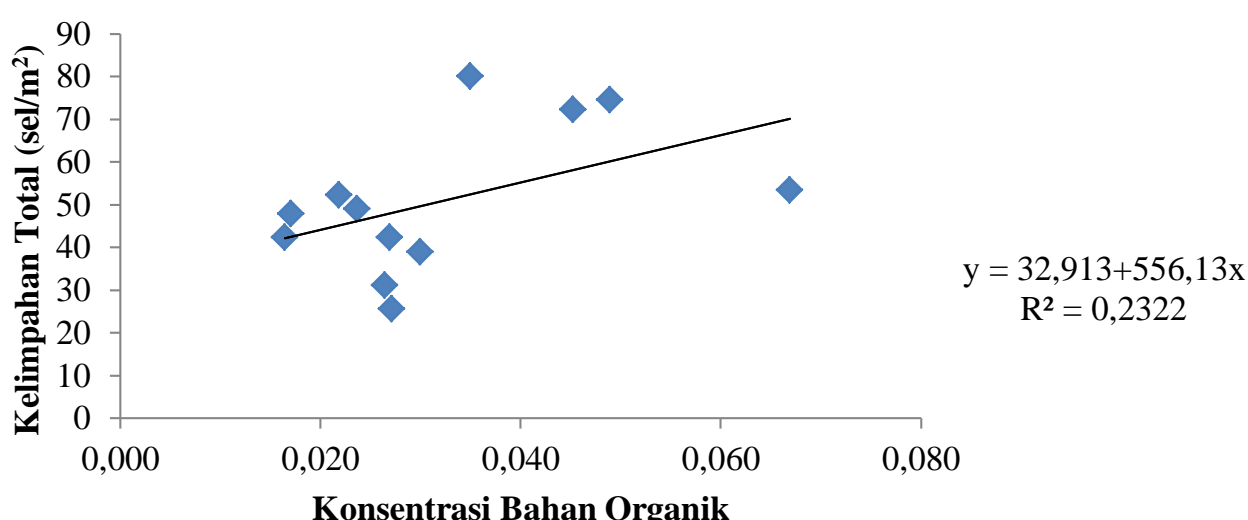

Gambar 4. Hubungan Konsentrasi Bahan Organik terhadap Kelimpahan Dinoflagelata

Hasil analisis regresi linear sederhana hubungan antara konsentrasi bahan organik dengan kelimpahan dinoflagelata mempunyai hubungan positif dengan persamaan regresi $\mathrm{y}=32,913+556,13 \mathrm{x}$, koefisien determinasi $\left(\mathrm{R}^{2}\right)$ dengan nilai 0,2322 dan Koefisien korelasi (r). Adapun Koefisien korelasi (r) dengan nilai 0,481yang berarti konsentrasi bahan organik mempunyai hubungan yang sedang terhadap kelimpahan dinoflagellata. Hal tersebut menunjukkan terdapatnya faktor lingkungan lain selain nutrien yang mempengaruhi kelimpahan dan distribusi sel dinoflagellata bentik beracun.

Hubungan antara konsentrasi bahan organik terhadap kelimpahan dinoflagellata, memiliki hubungan positif yang sedang.dimana semakin tinggi konsentrasi bahan organik maka kelimpahan dinoflagelata akan meningkat. Berdasarkan penelitian sebelumnya Rinja (2016) menyatakan hasil perhitungan analisis regresi kandungan bahan organik, kelimpahan fitoplankton dan zooplankton diperoleh koefisien determinasi $\left(\mathrm{R}^{2}\right)$ dan koefisien korelasi $(\mathrm{R})$ yang menunjukkan bahwa terdapat hubungan yang kuat antara kelimpahan fitoplankton.

\section{KESIMPULAN DAN SARAN}

\section{Kesimpulan}

Rata-rata bahan organik pada kawasan perairan pantai Desa Teluk Bakau berkisar 0,043 - 0,024 \%. Kelimpahan dinoflagellata tertinggi terdapat pada stasiun $275,615 \mathrm{sel} / \mathrm{m}^{2}$. Sementara nilai kelimpahan terendah pada stasiun 135,176 $\mathrm{sel} / \mathrm{m}^{2}$. Kelimpahan dinoflagellata didominasi oleh 3 genus yaitu, Gambierdiscus, Ostreopsis dan Prorocentrum, adapun kelimpahan genus tertinggi adalah Prorocentrum pada stasiun 2 dengan kelimpahan $46,333 \mathrm{sel} / \mathrm{m}^{2}$ dan kelimpahan pada genus terendah adalah Ostreopsis pada stasiun 1 dengan nilai kelimpahan $5,931 \mathrm{sel} / \mathrm{m}^{2}$. Hasil uji regresi linear sederhana menunjukkan koefisien korelasi (r) 0,481 yang berarti konsentrasi bahan organik mempunyai hubungan positif yang sedang terhadap kelimpahan dinoflagellata.

\section{Saran}

Penelitian selanjutnya disarankan untuk melakukan penelitian terhadap lokasi substrat yang bebeda agar dapat membandingkan pengaruh jenis sedimen (substrat) tempat menempel dinoflagellata terhadap kelimpahannya pada lokasi yang sama atau berbeda. 


\section{DAFTAR PUSTAKA}

1. Anderson and P. S. Lobel. (1987). The Continuing Enigma of Ciguatera Biological Bulletin. Volume 172 (1) Pages 89-107.

2. Bomber, J.W., D.R. Norris dan L.E. Mitchell. (1985). Benthic Dinoflagellates Associated with Ciguatera from the Florida Keys II. Temporal, Spatial and Substrate Heterogenity of Prorocentrum lima. Elsevier Science Publishing, New york Volume 1(1) Pages 45-50.

3. Delgado, G., C.H. Lechuga-Deveze, G. Popowski dan L. Troccoli. (2006). Epiphytic Dinoflagellates associated with Ciguatera in the Northwestern Coast of Cuba. Rev. Biol. Trop. Volume 54(2) Pages 299-310

4. Dwivayana, T.M.S. (2015). Analisis Kelimpahan Dinoflagellata Bentik Pada Substrat Buatan di Perairan Kota Padang Sumatera Barat. Tesis. Program Pascasarjana Universitas Riau. Pekanbaru

5. Faust, M. A. (2000). Dinoflagellata Associations in a Coral-Reef Mangrove Ecosytem: Pelican and Associated Cays, Belize (P. 534). Atoll Reasearch Bulletin.

6. Ira. (2011). Keterkaitan Padang Lamun Sebagai Pemerangkap Dan Penghasil Bahan Organik Dengan Struktur Komunitas Makrozoobentos di Perairan Pulau Barrang Lompo. [Tesis]. Institut Pertanian Bogor, Bogor.

7. Kantor Desa Teluk Bakau. (2018). Profil Desa Teluk Bakau. Kantor Desa Teluk Bakau. Keepulauan Riau.

8. Lalli, C.M. dan Parsons, T.R. (2006). Biological Oceanography (P: 307): An introduction. Elsevier, Oxford.

9. Marwan. (2012). Kandungan Bahan Organik dan Kelimpahan Makrozoobenthos Sebagai Indikator PencemaranPerairan Pantai Tanjung Uban Kepulauan Riau. Pekanbaru.

10. Nitajohan. Y. P. (2008). Kelimpahan Dinoflagellata Epibentik Pada Lamun Enhalus acoroides (L.F) Royle Dalam Kaitannya Dengan Parameter Fisika-Kimia Di Ekosistem Lamun. FPIK, IPB, Bogor.

11. Nugroho, S. H. dan A. Basit. (2014). Sebaran Sedimen Berdasarkan Analisis Ukuran Butir Di Teluk Weda, Maluku Utara. Fakultas Perikanan dan Ilmu Kelautan, Institut Pertanian Bogor Volume 6(1) Pages 229-240.

12. Rinja, A.K. (2016). Kandungan Bahan Organik Dan Komunitas Plankton Di Perairan Mangrove Baros Kabupaten Bantul.Univeristas Gajah Mada. Yongyakarta

13. Roito, M. (2014). Analisis Komunitas Diatom Planktonik di Perairan Pulau Topang Kabupaten Kepulauan Meranti Provinsi Riau.

14. Sugiyono, (2008). Metode Penelitian Kunatitatif Kualitatif dan R\&D. Bandung Alfabeta.

15. Supriyadi, S. (2008). Kesuburan Tanah Lahan Kering Madura. Embryo Volume 5(2) Pages 124-131.

16. Yesou. (2013). Project Information and Methods. Use Of An Artificial Substrate To Assess Field Abundance Of Benthic HAB (BHAB) Dinoflagellates. January. 